НАУКОВИЙ ВІСНИК

Scientific messengerer of Livi National University of
Veterinary Medicine and Biotechnologies

(1)

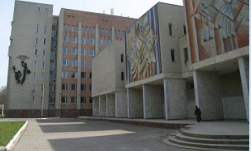

СЕРЯя: ВЕтЕРинАРнн нАУКИ
Науковий вісник Аьвівського національного університету ветеринарної медицини та біотехнологій імені С.3. Гжицького. Серія: Ветеринарні науки

Scientific Messenger of Lviv National University of Veterinary Medicine and Biotechnologies. Series: Veterinary sciences

UDC 636.52/.58.09:577.112/.115

\title{
Indicators of protein metabolism and intensity of lipid peroxide oxidation in chickens with different vegetative status
}

\author{
A. A. Studenok ${ }^{1}$, E. O. Shnurenko ${ }^{1}$, V. I. Karpovskyi ${ }^{1}$, V. O. Trokoz ${ }^{1}$, B. V. Gutyj ${ }^{2}$ \\ ${ }^{I}$ National University of Life and Environmental Sciences of Ukraine, Kyiv, Ukraine \\ ${ }^{2}$ Stepan Gzhytskyi National University of Veterinary Medicine and Biotechnologies, Lviv, Ukraine
}

\section{Article info}

Received 21.04.2021 Received in revised form 27.05.2021 Accepted 28.05.2021

National University of Life and Environmental Sciences of Ukraine, Heroiv Oborony Str., 15 Kyiv, 03041, Ukraine. Tel.: +38-050-503-57-78 E-mail: artemstudenok@gmail.com

Stepan Gzhytskyi National University of Veterinary Medicine and Biotechnologies Lviv, Pekarska Str., 50, Lviv, 79010, Ukraine. Tel.: +38-068-136-20-54 E-mail:bvh@ukr.net
Studenok, A. A., Shnurenko, E. O., Karpovskyi, V. I., Trokoz, V. O. \& Gutyj, B. V. (2021). Indicators of protein metabolism and intensity of lipid peroxide oxidation in chickens with different vegetative status. Scientific Messenger of Lviv National University of Veterinary Medicine and Biotechnologies. Series: Veterinary sciences, 23(102), 110-118. doi: 10.32718/nvlvet10217

The tone of the autonomic nervous system, protein metabolism and enzymes in Cobb-500 crossbred chickens aged 35 and 60 days were studied. The experiment involved 24 chickens, 8 in each group. In birds, the tone of the autonomic nervous system was determined by the method of variation pulsometry. The essence of the method is to record the effect of sympathetic and parasympathetic systems on heart rate in chickens. The effect was determined by recording one hundred consecutive cardio intervals and counting the time interval between each cardiocycle. Venous blood samples were taken from each individual at the age of 35 and 60 days to determine the indicators of protein metabolism (total protein, albumin, globulins) and lipid peroxidation depending on the tone of the autonomic nervous system. It was found that the antioxidant level in chickens with a predominance of the sympathetic division prevailed in all other groups regardless of the age of the bird. At 35 days of age, plasma concentrations of diene conjugates were significantly higher in normatonics and vagotonics $(P<0.05)$. There was a higher level of activity of ketodienes and Schiff bases in chickens with a predominance of the sympathetic division of autonomic nervous regulation compared with normotonics and vagotonics $(P<0.01)$. The content of total protein, albumin and globulins prevailed in normotonic hens and was the lowest in vagotonic hens at the age of 35 days. The two-month-old bird with a dominant parasympathetic division of the autonomic nervous system and normotonic hens had the highest levels of total protein, globulins, and conversely, sympathicotonic hens outnumbered the latter in albumin levels. Histidine content was highest in chickens with a balanced type of autonomic nervous system compared to sympathicotonics and vagotonics $(P<0.05)$. The concentration of sulfur-containing amino acid methionine was highest in vagotonic chickens $(P<0.05)$ compared with sympathicotonics. Threonine was highest in sympathicotonics compared with other groups of animals and significantly outweighed vagotonics $(P<0.05)$. The level of lipid peroxidation products in 60-day-old sympathicotonic chickens was consistently higher in contrast to normotonics and vagotonics. At the same time there was the smallest increase in the activity of diene conjugates and ketodienes $(P<0.05)$ in chickens with a dominant sympathetic division of the autonomic nervous system, which indicates a slowdown in the accumulation of the final products of lipid peroxidation.

Key words: autonomic nervous regulation, lipid peroxidation, protein metabolism, chickens.

\section{Показники обміну білка та інтенсивності пероксидного окиснення ліпідів у курей 3 різним вегетативним статусом}
А. А. Студенок ${ }^{1}$, Е. О. Шнуренко ${ }^{1}$, В. І. Карповський ${ }^{1}$, В. О. Трокоз ${ }^{1}$, Б. В. Гутий ${ }^{2}$
${ }^{1}$ Національний університет біоресурсів і природокористування України, м. Київ, Україна
${ }^{2}$ Львівський національний університет ветеринарної медицини та біотехнологій імені С. 3. Гюицького, м. Львів, Україна 
Досліджено тонус тонус автономної нервової системи, показники обміну білка та ензими у курей кроссу Кобб-500 віком 35 -ть та 60-т діб. В експерименті брали участь 24 курки по 8 в кожній групі. У птиці визначали тонус автономної нервової системи методом варіаційної пульсометрії. Суть методу полягає у реєстрації впливу симпатичної та парасимпатичної систем на частоту серцевих скорочень у курей. Вплив визначали за допомогою реєстрації ста послідовних кардіоінтервалів та підрахунку часового проміжку між кожним кардіочиклом. У кожної особини проводили відбір проб венозної крові у вічі 35 та 60 діб для визначення показників обміну білка (загального білка, альбумінів, глобулінів) та пероксидного окиснення ліпідів залежно від тонусу автономної нервової системи. Було встановлено, що антиоксидантний рівень у курей з домінуванням симпатичного відділу переважав всі інші групи незалежно від віку птиці. У 35-денному віці у курей-симпатикотоніків вміст дієнових кон 'югатів в плазмі крові був достовірно більший, ніж у нормотоніків та ваготоніків $(P<0,05)$. Виявлено вищій рівень активності кетодієнів та основ Шиффа у курей з переважанням симпатичного відділу автономної нервової регуляції порівняно із нормотоніками та ваготоніками (Р < 0,01). Вміст загального білка, альбумінів та глобулінів переважав у курей-нормотоніків $і$ був найнижчим у курей-ваготоніків віком 35 діб. Птичя дво місячного віку з домінуючим парасимпатичним відділом автономної нервової системи та кури-нормотоніки мали найвищі рівні по загальному білку, глобулінів і навпаки кури-симпатикотоніки переважали останніх по рівню альбумінів. Вміст гістидину був найвищим у курей з урівноваженим типом автономної нервової системи порівняно з симпатикотоніками та ваготоніками $(P<0,05)$. Концентрація сірковмісної амінокислоти метіоніну була найвищою у курей-ваготоніків (P < 0,05) порівняно із симпатикотоніками. Треонін був найвищим у симпатикотоніків порівняно з іншими групами тварин та достовірно переважав ваготоніків $(P<0,05)$. Рівень продуктів перекисного окиснення ліпідів у 60-денних курей-симпатикотоніків мав стабільно вищі показники навідміну від нормотоніків та ваготоніків. При цьому виявлено найменше збільшення активності утворення дієнових кон'югатів та кетодієнів $(P<0,05)$ у курей з домінуючим симпатичним відділом автономної нервової системи, цио свідчить про уповільнення накопичення кінцевих продуктів перекисного окиснення ліпідів.

Ключові слова: автономна нервова регулячія, пероксидне окиснення ліпідів, білковий обмін, кури.

\section{Вступ}

Останні десятиліття зростання інтенсивності технології виробництва у птахівництві та постійне поліпшення генетичного потенціалу птиці створює передумови для підвищення темпів приросту маси тіла та ефективності дорощування (Havenstein et al., 2003). Збільшення інтенсивності обмінних процесів у організмі птиці сприяє швидкому засвоюванню поживних речовин, ранній скоростиглості та високій продуктивності (Kyryliv et al., 2015). Зокрема, від інтенсивності обміну білка залежить м'язово-жирове співвідношення, рівень фракцій білків та вміст амінокислот в сироватці крові (Gotovsky et al., 2018). Одним із основних факторів впливу на обмін речовин та адаптацію тварин до ендо- та екзогенних подразників $є$ оксидаційний стрес (Brambilla et al., 2002). Незважаючи на те, що вільні радикали, які утворюються в організмі, відіграють важливу роль у процесах метаболізму, їх надлишкове утворення супроводжується інтенсифікацією пероксидного окиснення ліпідів, зниженням інтенсивності клітинного дихання та активності системи антиоксидантного захисту (Lushchak et al., 2006).

Регуляцію росту та розвитку організму як тварин, так і людини здійснює нейро-гуморальна система (Conde-Sieira et al., 2020). Вона відіграє важливу роль у процесах адаптації організму до змін умов навколишнього середовища (Opalovskaya, 2001). Доведено вплив автономної та центральної нервової системи на метаболізм білків, амінокислот, глюкози у печінці тварин та риб (Püschel, 2004; Conde-Sieira et al., 2019; 2020; Danchuk et al., 2020). Вегетативна нервова система регулює всі внутрішні процеси організму, відносну динамічну сталість внутрішнього середовища та, зокрема, бере участь у регуляції активності системи антиоксидантного захисту та інтенсивності пероксидного окиснення ліпідів у організмі відповідно до умов навколишнього середовища (Opalovskaya, 2001).

Відомо, що повноцінний амінокислотний пул має важливе значення для гомеостазу зокрема, недостатність хоча б однієї незамінної амінокислоти викликає порушення обміну речовин, зменшується, або навіть припиняється ріст і розвиток організму (Castro et al., 2019). Визначення зв'язку між вегетативним статусом та обміном білка у бройлерів надасть значний поштовх у подальшому розвитку птахівництва, а вивчення процесів пероксидного окислення ліпідів у курей з різним тонусом автономної нервової системи дозволить поглибити існуючі знання про вегетативну регуляцію фізіологічних функцій організму птахів, розробити нові методи корекції інтенсивності пероксидного окиснення ліпідів, а також дасть підгрунтя для розробки нового типу утримання курей із урахування особливостей автономної нервової регуляції.

Однак, дослідження вегетативної регуляції білкового обміну та інтенсивності пероксидного окиснення ліпідів, іiі впливу на продуктивність у птахів наразі залишаються поза увагою дослідників. Невелика кількість інформаційних даних за визначенням тонусу автономної регуляції у курей може свідчити про відсутність або недосконалість адаптованих методів дослідження з урахуванням фізіологічних особливостей роботи серцево-судинної системи у птахів. Старкі П. Д. вперше застосував клінічну електрокардіографію у птахів і описав нормальну електрокардіограму курки, використовуючи стандартні біполярні відведення кінцівок. Незважаючи на велику клінічну ефективність, електрокардіографії птахів майже не приділяли уваги. Це може бути пов'язано з дефіцитом референтних електрокардіографічних значень у птахів (Sturkie, 1986).

Мета $і$ завдання дослідження. Визначити вплив різного тонусу АНС на вміст білкових компонентів у сироватці крові та інтенсивності пероксидного окиснення ліпідів курей мясного спрямування різного віку.

\section{Матеріал і методи досліджень}

Дослідження обміну білка та пероксидного окислення ліпідів у курей-бройлерів залежно від тонусу автономної нервової системи проводили на 24-х курях 
м’ясного напрямку продуктивності породи Кобб-500, 35-60-добового віку із підлоговим типом утримання на глибокій підстилці. На першому етапі досліджень визначали тонус автономної нервової системи шляхом 3 використанням електрокардіографії. Для цього застосовували переносний електрокардіограф ЭК3Т 01-«Р-Д». Під час запису електрокардіограми використовували стандартні відведення - I ліва і права грудні кінцівки, II - ліва грудна і ліва тазова кінцівки, III права грудна і ліва тазова кінцівки. Швидкість руху стрічки становила $50 \mathrm{~mm} / \mathrm{c}$, амплітуда -1 мВ. Запис електрокардіограм проводили протягом 20-30 секунд. Це дозволило зробити запис близько 100-120 ЕКГкомплексів (кардіоінтервалів). Процедуру електрокардіографії проводили в тихому приміщенні. Голови птахів під час маніпуляцій були прикриті тканиною, що мало заспокійливий вплив на піддослідних. Фіксація курей проводилась у спинному положенні. Електроди алігаторного типу були прикріплені на шкіру в ділянці плечової та стегнової кістки. Запис електрокардіограми починали через 2-3 хвилини після під'єднання електродів (Machida \& Aohagi, 2001; Reddy et al., 2016). Під час електрокардіологічного дослідження була відсутність використання седативних лікарських засобів, які впливають на частоту та проведення серцевих імпульсів.

Спектральний аналіз варіабельності серцевого ритму (ВРС) широко вважається стандартним неінвазивним методом оцінки функції автономної нервової системи (Messina et al., 2012). Симпатична активність пов'язана з низьким (НЧ; 0,04-0,15 Гц), тоді як парасимпатична - 3 більш високим частотним діапазоном (ВЧ; 0,15-0,4 Гц) модуляції частоти серцевих скорочень. Дана особливість дозволяє провести діагностику домінуючого тонусу автономної нервової системи у досліджуваної тварини.

Обробку отриманих електрокардіограм проводили методом варіаційної пульсометрії шляхом підрахунку 100 R-R кардіоінтервалів. При цьому визначали два основних показники: моду (Мо) та амплітуду моди (Амо). Тривалість моди для тварин-симпатикотоніків становила 0,14-0,16 с. (перевага симпатичного відділу автономної нервової системи); нормотоніків - 0,160,17 с. (рівновага тонусу симпатичного та парасимпатичного відділу автономної нервової системи); ваготоніків - 0,18-0,21 с. (перевага парасимпатичного тонусу автономної нервової системи). Амплітуду моди використовують як додатковий параметр для уточнення тонусу автономної нервової системи: симпатотонія $>45 \%$, нормотонія - 40-45\%, ваготонія < $40 \%$ (Studenok et al., 2020). Таким чином за отриманими результатами піддослідна птиця була поділена на три групи відповідно до тонусу відділів автономної нервової системи: симпатотоніки, нормотоніки та ваготоніки (по 8 тварин у кожній групі).

На другому етапі у кожної тварини 35-добового віку відбирали венозну кров після 2-годинної голодної дієти з підкрилової вени. В плазмі крові визначали вміст продуктів пероксидного окислення ліпідів (ке- тодієни, основи Шиффа, дієнові кон'югати) спектрофотометричним методом, принцип якого базується на тому, що процес пероксидного окиснення ліпідів супроводжується переорієнтацією подвійних зв'язків iз виникненням специфічних оптичних властивостей (Stalnaya, 1977; Kondrakhin et al., 2004; Khuzhakhmetova \& Teply, 2016; Danchuk et al., 2018). У сироватці крові визначали вміст загального білка (біуретовим методом) та альбуміну (методом з бромкрезоловим зеленим) на напівавтоматичному біохімічному аналізаторі BiosystemsA15 (Іспанія) 3 використанням набору реактивів PointerScientific (США). Визначення вмісту амінокислот проводили методом капілярного електрофорезу на апараті "Капель 105М" (Komarova \& Kamentsev, 2006; Kaneko et. al., 2008; Thrall et al., 2012; Corbridge, 2013).

Третій етап дослідження проводився у 60-денному віці курей різних груп, в яких повторно проводили забір венозної крові та визначали продукти білкового обміну та пероксидного окиснення ліпідів за наведеними вище методиками.

Статистичні підрахунки проводили за допомогою пакету аналізу даних в програмі Microsoft Excel 2016, зокрема, визначали середньоарифметичну величину (M) та іiі похибку (m), ймовірність різниць середніх значень встановлювали за критерієм Стюдента. Зміни показників вважали достовірними при $\mathrm{P}<0,05$ (в тому числі $\mathrm{P}<0,01$ і $\mathrm{P}<0,001)$. Коефіцієнт кореляції (r) розраховували методом Пірсона.

\section{Результати та їх обговорення}

Відповідно до встановленої класифікації, переважання тонусу парасимпатичної частини автономної нервової системи в організмі називається ваготонією, а симпатичної - симпатикотонією. Також існує нормотонія - тонус обох відділів автономної нервової системи є врівноваженим (Navarro, 2002). Випробуваннями типів автономної нервової системи у курей було виявлено найнижчі показники моди у поєднанні iз найвищими значеннями частоти серцевих скорочень у курей-симпатотоніків порівняно із нормо - та ваготоніками (табл. 1).

Нами встановлено, що середнє значення моди у симпатотоніків було на $8,54 \%$ та $12,79 \%$ ( $<<0,001 * * *)$ менше за нормотоніків та ваготоніків, відповідно. Виявлення корелятивних зв'язків між значенням моди та частоти серцевих скорочень у симпатотоніків $\mathrm{r}=-0,577$ та ваготоніків $\mathrm{r}=-0,996$ (P $<0,001 * * *)$ підтверджує вплив збільшення тонічної активності у центрах симпатичного або парасимпатичного відділу автономної нервової системи на регуляцію серцевого ритму у курей. При цьому у нормотоніків спостерігаються негативні кореляційні взаємозв'язки між показниками моди та частотою серцевих скорочень, що вказує на схильність цього типу до врівноваження серцевого ритму із активністю центрів автономної нервової системи (рис. 1). 
Таблиця 1

Показники тонусу автономної нервової регуляції $(\mathrm{M} \pm \mathrm{m}, \mathrm{n}=8)$

\begin{tabular}{lcc}
\hline \multicolumn{1}{c}{ Показники АНС } & \multicolumn{2}{c}{ Вегетативний статус } \\
\cline { 2 - 3 } & Симпатотоніки & Нормотоніки \\
\hline Мода, сек & $0,15 \pm 0,005 * * *$ & $0,164 \pm 0,007$ \\
Амплітуда моди, \% & $53 \pm 10,39$ & $51 \pm 9,172 \pm 0,013$ \\
ЧСС, уд/хв & $404 \pm 7,41 * * *$ & $366 \pm 18,57$ \\
\hline
\end{tabular}

Примітка: $\mathrm{P}<0,05^{*}, \mathrm{P}<0,01^{* *}, \mathrm{P}<0,001^{* * *}$

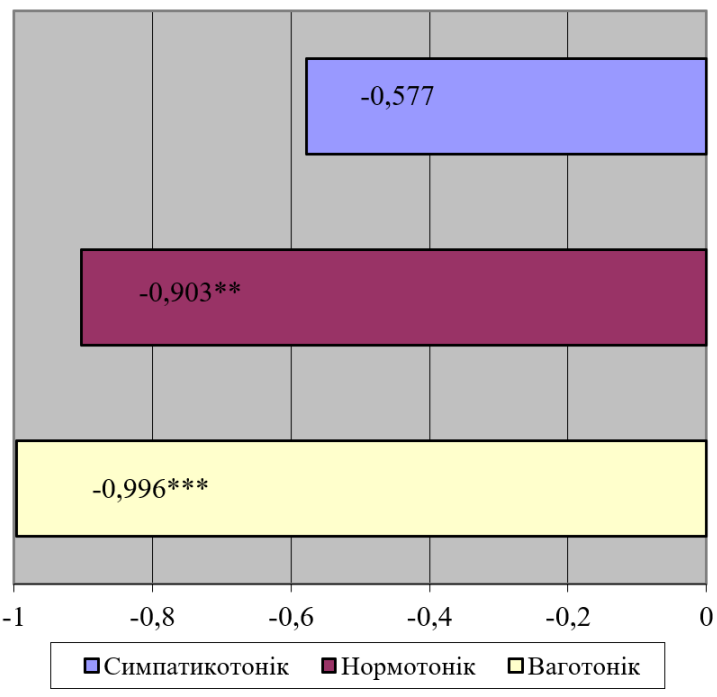

Рис. 1. Взаємозв'язок моди та частоти серцевих скорочень в залежності від типів автономної нервової системи у курей $(\mathrm{r}, \mathrm{n}=8)$

Примітка: коефіцієнт кореляції достовірний при $\mathrm{P}<0,01 * *$, $\mathrm{P}<0,001 * * *$

Слід відмітити наявність прямих кореляційних зв'язків між амплітудою моди та частоти серцевих скорочень у курей всіх типів автономної нервової регуляції $-\mathrm{r}=0,74-0,94$ ( $\mathrm{P}<0,05-0,001)$. У курейваготоніків відмічається більш тісна взаємодія між частотою серцевих скорочень та Амо порівняно із іншими типами АНС (рис. 2).

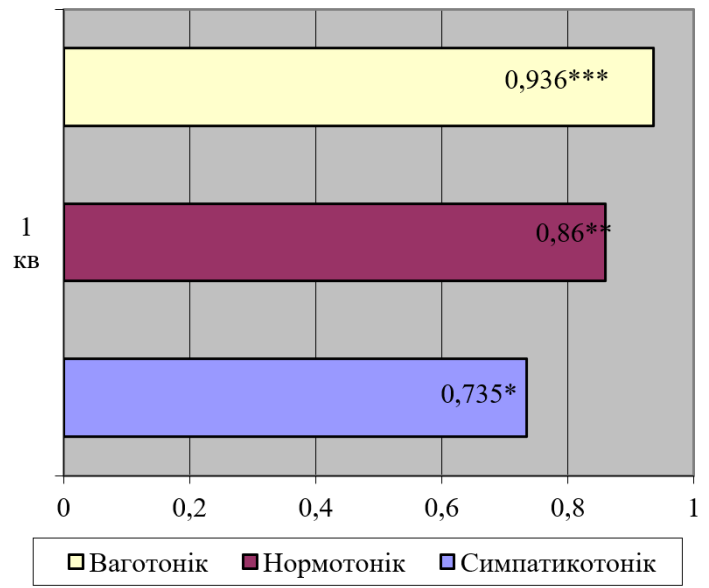

Рис. 2. Кореляція амплітуди моди із частоти серцевих скорочень у курей із різними типами автономної нервової ситеми

Примітка: коефіцієнт кореляції достовірний при $\mathrm{P}<0,05^{*}, \mathrm{P}$ $<0,01^{* *}, \mathrm{P}<0,001^{* * *}$
Таке поєднання та взаємовплив показників моди, амплітуди моди та частоти серцевих скорочень дало можливість достовірно визначити три типи автономної регуляції у курей із урахування видоспецифічних особливостей тонусу вегетативної нервової системи, на відміну від попередників, які чітко відмічали лише один тип автономної нервової системи у курей - симпатотонічний (Tybinka, 2011).

Вальтер Каннонар стверджував, що автономна нервова система підтримує гомеостаз та регулює стабільність внутрішньої матричної рідини, необхідної для підтримання життя. Ця функція була запропонована завдяки ряду регульованих зворотним зв'язком автономних рефлексів, що реагують на збудження у вісцеральних станах $з$ компенсаційними регулюваннями для відновлення гомеостатичного балансу. Прикладом $\epsilon$ рефлекси барорецепторів, в результаті збудження яких відбувається підвищення артеріального тиску, запускаються рефлекторні реакції, які включають розслаблення гладеньких м'язів судин, а також зменшує частоту серцевих скорочень і скоротливість міокарда. Таким чином, тонус автономної нервової системи можна розглядати не тільки як один із проявів гомеостазу, а також як один 3 механізмів його регуляції (West, 2010).

Енергетичний гомеостаз регулюється складною мережею нейроендокринних та вегетативних шляхів (Danchuk et al., 2020), де гіпоталамус відіграє ключову роль моніторингового сигналу, який відображає енергетичний стан, ініціюючи відповідні метаболічні відповіді та поведінку (Esposito et al., 2016). Вплив автономної нервової системи на обмін речовин, було продемонстровано в дослідженні варіабельності серцевого ритму у худорлявих жінок та тих, що страждають на ожиріння.

У результаті наших досліджень сироватки крові встановлено, що у курей 35-добового віку з різним тонусом автономної нервової є статистичні відмінності майже за всіма показниками білкового обміну (табл. 2).

Вміст загального білка у курей з урівноваженим тонусом АНС був найвищим у віці 35 діб і переважав ваготоніків на 7,6 г/л $(17,3 \%$; Р < 0,001) та симпатикотоніків на 4 г/л $(9,1 \%)$. Різниця між останніми становила 3,6 г/л $(9 \%$; $\mathrm{P}<0,05)$. Альбумін також був найвищим у курей-нормотоніків та переважав тварин 3 домінування парасимпатичної гілки АНС на 3,05 г/л $(15,25 \%$; Р < 0,001). Кури-симпатиктоніки теж мали нижчий вміст альбуміна порівняно 3 нормотоніками на 1,6 г/л (8 \%). Різниця між симпатикотоніками та ваготоніками складала 1,45 г/л (7,9 \%). Рівень глобу- 
ліна був найвищим у курей з урівноваженим типом АНС, його вміст перевищював на 2,35 г/л (9,8 \%) та 4,54 г/л $(19 \%$; $>$ < 0,01) у курей симпатикотоніків та ваготоніків. Кури симпатикотоніки теж мали достовірно вищі показники глобуліна порівняно з ваготоніками на 2,19 г/л (10,2 \%; Р < 0,05).

Підвищений вміст альбумінової фракції у нормотоніків та симпатикотоніків забезпечує кращий тран- спорт сполук - гормонів, вільних жирних та жовчних кислот, білірубіну (Crane \& Miller, 1977).

3 віком відбувається врівноваження метаболічних процесів, перехід від інтенсивного росту та нарощування м'язової маси у плато сталих показників. Особливо це помітно у курей-ваготоніків, у яких підвищувались показники білкового обміну та у віці 60 діб наблизились до результатів тварин із домінуючим симпатичним та урівноваженим тонусом АНС.

Таблиця 2

Показники обміну білка курей з різним тонусом автономної нервової системи віком 35 та 60 діб, г/л $(\mathrm{M} \pm \mathrm{m}, \mathrm{n}=8)$

\begin{tabular}{lccc}
\hline \multirow{2}{*}{ Тип АНС } & \multicolumn{3}{c}{ Вміст у сироватці крові } \\
\cline { 2 - 4 } & Загальний білок, г/л & Альбуміни, г/л & Глобуліни, г/л \\
\hline Симпатикотоніки & $39,9 \pm 1,46^{* 1}$ & У віці 35 діб & $21,55 \pm 0,59^{* 1}$ \\
Нормотоніки & $43,9 \pm 1,25^{* * * 1}$ & $18,4 \pm 0,98$ & $23,9 \pm 1,0^{* * 1}$ \\
Ваготоніки & $36,3 \pm 0,84$ & $16,0 \pm 0,61^{* * * 1}$ & $19,36 \pm 0,59$ \\
\hline & $39,9 \pm 0,67$ & У віці 60 діб & $20,9 \pm 0,45$ \\
\hline Симпатикотоніки & $41,7 \pm 1,5$ & $19 \pm 0,37$ & $22,85 \pm 0,99$ \\
Нормотоніки & $41,7 \pm 0,97$ & $17,96 \pm 0,56$ & $23,78 \pm 0,76^{* * 2}$ \\
Ваготоніки & &
\end{tabular}

Примітка: ${ }^{* 1}-\mathrm{P}<0,05 ; * * 1-\mathrm{P}<0,01 ; * * * 1-\mathrm{P}<0,001$ порівняно з ваготоніками; ${ }^{* * 2}-\mathrm{P}<0,01$ порівняно 3 симпатикотоніками

Динаміка загального білка, альбуміна та глобуліна курей із урівноваженим типом АНС у період 3560 діб вирощування мала динаміку до зниження. Вміст зального білка знизився на 2,2 г/л (3 \%), альбумін на 1,1 г/л (5,5\%), глобулін на 1,05 г/л (4,4\%). Схожа динаміка спостерігалась у курей із домінуванням симпатичного тонусу АНС. Вміст загального білка був однаковий на 35 та 60 добу вирощування. Глобулінова та альбумінова фракції мали незначні коливання. Глобулін знизився на 0,65 г/л (3\%); альбумін збільшувався на 0,6 г/л (3,1%). Куриваготоніки мали стійке зростання білкових фракцій у сироватці крові в період досліджень. Загальний білок та глобулінова фракція мала стрімкий зріст на 5,4 г/л $(12,3 \% ; \mathrm{P}<0,001)$ та 4,42 г/л $(18,6 \% ; \mathrm{P}<0,001)$. Альбумін зріс незначно на 1 г/л $(5,6 \%)$ порівняно 3 попереднім періодом.

Дані зміни в білковому профілі птиці можуть вказувати на підвищення з віком синтезу білкових фракцій, посилення імунітету птиці 3 ваготонічним тонусом автономної нервової системи та покращене засвоєння білків корму в їх організмі (Kuznyak \& Savchuk, 2017).

Отже, парасимпатичний відділ автономної нервової системи, впливаючи на метаболізм білка через гуморальну (інсулін, адреналін, кортизол тощо) та центральну нервову стимуляцію гепатоцитів (Crane \& Miller, 1977; Püschel, 2004), викликає повільне підвищення рівня білків сироватки крові, а симпатичний відділ - навпаки, стримує цей процес.

Відомо, що для синтезу білка та пептидів будівельним і складовим матеріалом $\epsilon$ амінокислоти. Які відіграють невідємне значення у житті та функціонуванні всього організму (De Koning, 2013).

Встановлено, що вміст метіоніну в сироватці крові курей симпатикотоніків 60-добовому віці був на 2,76 мкмоль/л $(28,2$ \%; Р < 0,05) нижче, ніж у птиці 3 домінуванням парасимпатичного відділу автономної нервової системи та на 0,8 мкмоль/л (10,2\%) нижче від нормотоніків. Кури-ваготоніки мали на 20 \% нижчий вміст метіоніну, ніж тварини з урівноваженим тонусом автономної нервової системи (табл. 3). Нижчий вміст даної сполуки вказує на її підвищений катаболізм у тварин з домінуванням симпатичного відділу автономної нервової системи. Концентрація метіоніну в організмі тварин може знижуватись через його використання як джерела метальних груп при окисновідновних реакціях (Martínez et al., 2017; Garaeva, 2011). Ця амінокислота та низка інших сірковмісних сполук є одними з основних речовинами, що беруть участь у знешкодженні вільних радикалів (Garaeva, 2011).

\section{Таблиця 3}

Вміст окремих амінокислот в крові курей з різним тонусом автономної нервової системи віком 60 діб, мкм/л $(\mathrm{M} \pm \mathrm{m}, \mathrm{n}=4)$

\begin{tabular}{lccc}
\hline \multirow{2}{*}{ Тонус АНС } & \multicolumn{3}{c}{ Амінокислоти } \\
\cline { 2 - 4 } & Метіонін & Гістидин & $25,92 \pm 2,5^{+}$ \\
Симпатикотоніки & $7,04 \pm 0,4^{+}$ & $9,62 \pm 1,46^{*}$ & $22,73 \pm 1,64$ \\
Нормотоніки & $7,84 \pm 0,61$ & $14,1 \pm 0,97$ & $14,9 \pm 3,46$ \\
Ваготоніки & $9,8 \pm 0,79$ & $6,96 \pm 2,36^{*}$ &
\end{tabular}

Примітка: *P <0,05 порівняно з нормотоніками; ${ }^{+} \mathrm{P}<0,05$ порівняно $з$ ваготоніками 
Кури-нормотоніки мали найвищі рівні гістидину, що на 7,14 мкмоль/л $(50,6 \%$; $>0,05)$ вище, ніж у ваготоніків та на 4,48 мкмоль/л $(31,8 \%$; $>$ > 0,05) порівняно $з$ симпатикотоніками. Різниця між тваринами 3 домінуванням симпатичного та парасимпатичного відділів становила 2,66 мкмоль/л (31,5 \%) на користь останніх. Такий розподіл можна охарактеризувати зниженим метаболізмом та потребою амінокислоти як джерела енергії, антиоксиданта та нейромедіатора у курей-ваготоніків через їх переважно менш рухливий спосіб життя порівняно з іншими тваринами (Khlybova \& Cirkin, 2006; Garaeva, 2011).

Концентрація амінокислоти треоніну була статистично найвищою у симпатикотоніків $(\mathrm{P}<0,05)$ та нормотоніків (тенденція) порівняно з ваготоніками на 11 мкм/л (42,5 \%) і 7,83 мкм/л (34,4%). Різниця між симпатикотоніками та нормотоніками була не значна i становила 3,19 мкм/л.

Відомо, що в процесі життєдіяльності організму в клітині постійно утворюються вільні радикали. Активний ріст і розвиток, зміна фізіологічного стану, фізичне навантаження, адаптація та стрес супроводжується зміною інтенсивності процесі вільнорадикального окиснення в організмі, які, з одного боку, необхідні для оновлення клітинних мембран, синтезу ряду біологічно активних речовин, а 3 іншого, вільнорадикальне окиснення $є$ універсальним механізмом пошкодження біомембран при різних патологічних станах (Polumbryk et al., 2013).

Дослідження плазми крові у курей 35-добового віку показали достовірну залежність показників пероксидного окиснення ліпідів від типів автономної нервової регуляції (табл. 4).

\section{Таблиця 4}

Показники пероксидного окислення ліпідів у курей 35-денного віку в залежності від типів автономної нервової системи $(\mathrm{M} \pm \mathrm{m}, \mathrm{n}=8)$

\begin{tabular}{llcl}
\hline \multicolumn{1}{c}{ Показник } & \multicolumn{3}{c}{ Тонус автономної нервової системи } \\
\cline { 2 - 4 } & Ваготоніки & Нормотоніки & Симпатотоніки \\
\hline Дієнові кон'югати, $\mathrm{D}_{278 / \text { мг ліпідів }}$ & $0,338 \pm 0,012^{*}$ & $0,353 \pm 0,018$ & $0,376 \pm 0,016^{*}$ \\
Кетодієни ліпідів, $\mathrm{D}_{278 / \text { мг ліпідів }}$ & $0,085 \pm 0,005^{* *}$ & $0,093 \pm 0,005$ & $0,103 \pm 0,009^{* *}$ \\
Основи Шиффа, умовних одиниць $/ \mathrm{cm}^{3}$ & $0,290 \pm 0,014$ & $0,299 \pm 0,023$ & $0,331 \pm 0,016^{* *}$ \\
\hline
\end{tabular}

Примітка: $\mathrm{P}<0,05^{*}, \mathrm{P}<0,01^{* *}, \mathrm{P}<0,001^{* * *}$

У курей-симпатотоніків вміст дієнових кон'югатів в плазмі крові становив на $6,12 \%(\mathrm{P}<0,05)$ та на $10,11 \%(\mathrm{P}<0,05)$ більше за такий у нормотоніків та ваготоніків, відповідно. Оскільки ці ліпопероксиди є первинними та нестійкими метаболітами, їх велика кількість свідчить про більш вищий рівень накопичення токсичних продуктів пероксидного окиснення ліпідів у симпатотоніків порівняно із іншими групами курей. При цьому активність утворення кетодієнів та основ Шиффа у курей із перевагою симпатичного відділу автономної нервової системи була достовірно вищою, ніж у ваготоніків на $17,48 \%(\mathrm{P}<0,01)$ та $12,39 \%(\mathrm{P}<0,01)$ відповідно (рис. 3$)$. Вищий рівень основ Шиффа у симпатотоніків говорить про більш активну дестабілізацію та пошкодження клітинних мембран, на відміну від курей-ваготоніків та нормотоніків, у яких цей показник знаходиться майже на однаковому рівні. Це свідчить про те, що у курей із симпатотонічним тонусом автономної нервової системи тканини характеризуються більшою інтенсивністю процесів пероксидного окислення ліпідів. Показники пероксидного окиснення ліпідів у симпатотоніків в порівнянні із нормотоніками вищі, що свідчить про врівноваженість в системі утворення та знешкодження первинних продуктів пероксидного окиснення ліпідів у останніх. При цьому виявлено взаємозв'язок дієнових кон'югатів $(\mathrm{P}<0,05)$ та кетодієнів із ваготонічним типом регуляції $(\mathrm{P}<0,01)$, який мав тенденцію до зниження швидкості пероксидного окиснення внаслідок уповільнення процесів обміну речовин.

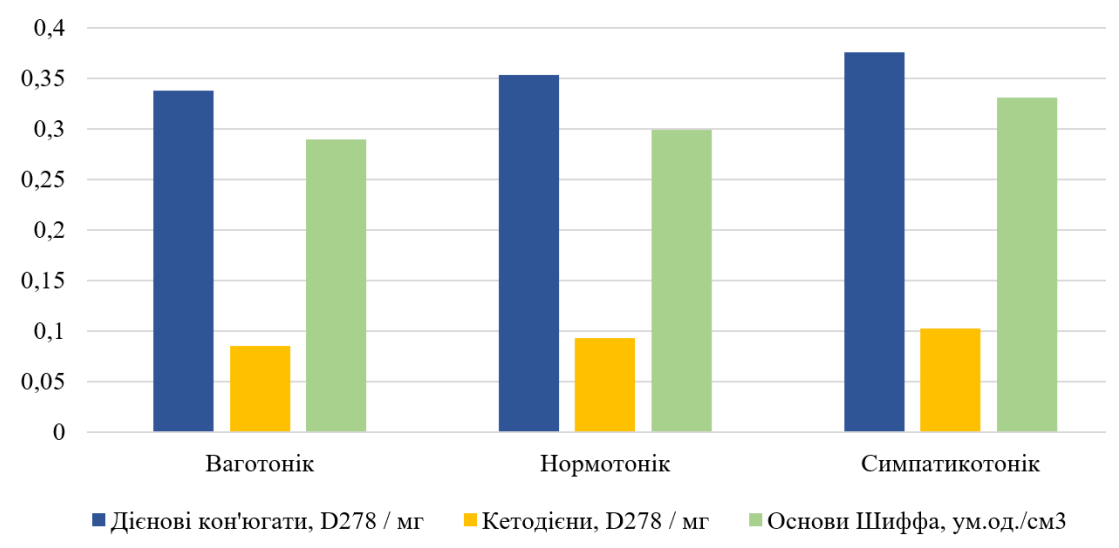

Рис. 3. Показники пероксидного окиснення ліпідів в залежності від тонусу автономної нервової системи у курей 
Одним із основних субстратів для вільнорадикальних реакцій є ліпіди, молекули поліненасичених жирних кислот, ліпідні компоненти ліпопротеїдів низької і дуже низької щільності. Продукти вільнорадикального пероксидного окиснення також можуть виступати своєрідними біомаркерами ушкодження тканин, оскільки за їх вмістом можна судити про інтенсивність перебігу вільно-радикальних процесів у різних системах організму (Trenzado et al., 2005). Найбільш важливими із них можуть виступати продукти окиснення поліненасичених жирних кислот. В результаті окислення жирних кислот утворюються гідроперекиси - дієнові кон'югати, кетодієни, які надалі метаболізуються у вторинні - малоновий діальдегід і третинні продукти пероксидного окислення ліпідів - шифрові основи (Zenkov et al., 2001). Активація пероксидного окиснення ліпідів являє собою універсальний пошкоджуючий механізм клітинних мембран, який протікає 3 утворенням вільних гідроксильних та ліпідних радикалів, що володіють високою реакційною здатністю (Meerson, 2001).

У курей 60-добового віку інтенсивність пероксидного окиснення ліпідів мала тенденцію до підвищення. При цьому у курей-симпатотоніків так само, як і в курей 35-добового віку, визначено стабільно найвищі показники пероксидного окиснення в плазмі крові (табл. 5).

\section{Таблиця 5}

Показники пероксидного окиснення ліпідів у курей 60-добового віку в залежності від тонусу автономної нервової системи $(\mathrm{M} \pm \mathrm{m}, \mathrm{n}=8)$

\begin{tabular}{llll}
\hline \multicolumn{1}{c}{ Показник } & \multicolumn{3}{c}{ Тонус автономної нервової системи } \\
\cline { 2 - 4 } & \multicolumn{1}{c}{ Ваготоніки } & Нормотоніки & Симпатотоніки \\
\hline Дієнові кон’югати, $\mathrm{D}_{278 / \text { мг ліпідів }}$ & $0,347 \pm 0,008^{* * *}$ & $0,372 \pm 0,013$ & $0,387 \pm 0,021^{*}$ \\
Кетодісни ліпідів, $\mathrm{D}_{278 / \text { мг ліпідів }}$ & $0,093 \pm 0,01$ & $0,098 \pm 0,009$ & $0,109 \pm 0,009^{*}$ \\
Основи Шиффа, умовних одиниць $/ \mathrm{cm}^{3}$ & $0,305 \pm 0,011^{*}$ & $0,326 \pm 0,011$ & $0,343 \pm 0,21^{*}$ \\
\hline
\end{tabular}

Примітка: $\mathrm{P}<0,05^{*}, \mathrm{P}<0,01^{* *}, \mathrm{P}<0,001^{* * *}$

Виявлено, що у симпатотоніків 60-денного віку порівняно із 35-добовим мали найменше збільшення активності утворення дієнових кон'югатів (на 2,84\%, Р < 0,05) та кетодієнів (на 5,51\%, Р < 0,05). Це свідчить про уповільнення накопичення токсичних продуктів пероксидного окиснення ліпідів, що може бути пов'язано із більш активним розвитком ензимного антиоксидантного захисту з віком тварин. У курейнормотоніків 60-добового віку, при цьому, виявлено найвищий рівень зростання утворення дієнових кон'югатів (на 5,11 \%) та основ Шиффа (на 8,28 \%) порівнянні із попереднім терміном дослідження, що може свідчити про збільшення з віком впливу симпатичного відділу автономної нервової системи.

\section{Висновки}

Взаємовплив показників моди, амплітуди моди та частоти серцевих скорочень дало можливість достовірно визначити три типи автономної нервової регуляції у курей (симпатотоніки, нормотоніки та ваготоніки). Відмічається достовірна позитивна лінійна взаємодія між Мо та Амо у курей з різним тонусом автономної нервової системи. У курей-ваготоніків кореляція $\mathrm{r}=$ 0,936 (P < 0,001) була вища порівнянно 3 птицеюсимпатикотоніками $\mathrm{r}=0,735$ ( $\mathrm{P}<0,05)$, що вказує більш тісний взаємозв'язок між частотою та діапазоном варіацій у ваготоніків. Натомість безпосередньо показник Амо у курей з домінуванням парасимпатичного тонуса був найменшим.

Встановлено вплив тонусу автономної нервової системи на обмін білків сироватки крові в організмі курей блойлерів. Показники загального білка, альбумінів, глобулінів та сечовини залежно від періоду вирощування мали статистично значимі коливання між групами курей. В перший період дослідження (35-добовий вік) тварини-нормотоніки демонстрували найвищі показники по білковим фракціям крові ( $\mathrm{P}<0,01 ; \mathrm{P}<0,001)$ порівняно 3 іншими групами. У віці 60 діб кури-симпатикотоніки мали найвищі показники альбуміну та найнижчий вміст глобулінової фракції порівняно 3 тваринами-ваготоніками ( $<<0,01 ;$ P $<0,05$ відповідно). Концентрація метіоніну була вища у нормотоніків порівняно з симпатикотоніками (Р $<0,05)$; вміст гістидину переважав у ваготоніків $(\mathrm{P}<0,05)$ в порівнянні з нормотоніками. Треонін був вищим у симпатикотоніків $(\mathrm{P}<0,05)$ порівняно $з$ нормотоніками.

Виявлено взаємозалежність типів автономної регуляції та пероксидного окиснення ліпідів. Кури із переважанням симпатичного відділу демонстрували підвищений вміст продуктів пероксидного окислення ліпідів у 35- та 60-денному віці (P <0,01, Р <0,05). Показники пероксидного окислення ліпідів у нормотоніків менше в порівнянні із симпатотоніками, що свідчить про врівноваженість в системі утворення та знешкодження первинних продуктів пероксидного окиснення. Встановлено найнижчий вміст продуктів пероксидного окиснення ліпідів у курей із ваготонічним типом автономної регуляції ( $\mathrm{P}<0,05, \mathrm{P}<0,01)$.

Таким чином, встановлено взаємовплив типів автономної нервової системи на показники білкового обміну та перекисного окиснення ліпідів у курейбройлерів, що дає можливість прогнозувати стресостійкість даних тварин та корегувати методики утримання із урахування їх типологічних особливостей, утворення стада високопродуктивної птиці.

Перспективи подальших досліджень - дослідження впливу тонусу автономної нервової системи на ендокринну функцію залоз внутрішньої секреції. Вза- 
ємозв'язок тонусу автономної нервової системи 3 іншими системами організму курей.

Відомості про конфлікт інтересів. Автори стверджують про відсутність конфлікту інтересів щодо їх вкладу та результатів наукових досліджень.

\section{References}

Brambilla, G., Civitareale, C., Ballerini, A. et al. (2002). Response to oxidative stress as a welfare parameterin swine. Redox Rep., 7(3), 159-163. doi: $10.1179 / 135100002125000406$.

Castro, F. L. S., Kim, Y., Xu, H. et al. (2019). The effect of total sulfur amino acid levels on growth performance, egg quality, and bone metabolism in laying hens subjected to high environmental temperature. Poultry science, 98(10), 4982-4993. doi: $10.3382 / \mathrm{ps} / \mathrm{pez} 275$.

Castro, F. L. S., Su, H., Choi, S. et al. (2019). L-Arginine supplementation enhances growth performance, lean muscle, and bone density but not fat in broiler chickens. Poultry science, 98(4), 1716-1722. doi: $10.3382 / \mathrm{ps} /$ pey504.

Conde-Sieira M., Capelli, V., Álvarez-Otero, R. et al. (2020). Hypothalamic AMPK $\alpha 2$ regulates liver energy metabolism in rainbow trout through vagal innervation. American Journal of Physiology-Regulatory, Integrative and Comparative Physiology, 18(1), 122134. doi: 10.1152/ajpregu.00264.2019.

Conde-Sieira, M., Capelli, V., Álvarez-Otero, R. et al. (2019). Differential Role of Hypothalamic AMPK $\alpha$ Isoforms in Fish: an Evolutive Perspective. Molecular Neurobiology, 56, 5051-5066. doi: 10.1007/s12035018-1434-9.

Corbridge, D. E. C. (2013). Phosphorus: chemistry, biochemistry and technology. CRC press, $6^{\text {th }}$ edition.

Crane L. J., \& Miller, D. L. (1977). Plasma protein synthesis by isolated rat hepatocytes. Journal of cell biology, 72(1), 11-25. doi: 10.1083/jcb.72.1.11.

Danchuk, O. V., Broshkov, M. M., Karpovsky, V. I. et al. (2020). Types of Higher Nervous Activity in Pigs: Characteristics of Behavior and Effects of Technological Stress. Neurophysiology, 52(5), 358-366. doi: 10.1007/s11062-021-09892-7.

Danchuk, O. V., Karposvkii, V. I., Tomchuk, V. A. et al. (2020). Temperament in Cattle: A Method of Evaluation and Main Characteristics. Neurophysiology, 52(1), 73-79. doi: 10.1007/s11062-020-09853-6.

Danchuk, O. V., Karpovskyi, V. I., \& Trokoz, V. O. (2018). Antioxidant-prooxidant status in organism of pigs with different types of higher nervous activity under stress. Scientific journal "Fiziologichnyi Zhurnal", 64(4), 26-32, doi: 10.15407/fz64.04.026.

De Koning, T. J. (2013). Amino acid synthesis deficiencies. Pediatric Neurology Part III, 40, 17751783. doi: 10.1016/b978-0-444-59565-2.00047-2.

Esposito, T., Lobaccaro, J. M., Esposito, M. G. et al. (2016). Effects of low-carbohydrate diet therapy in over weight subjects with autoimmune thyroiditis: possible synergism with ChREBP. DrugDes.Devel. Ther., 10, 2939-2946. doi: 10.2147/DDDT.S106440.

Garaeva, O. (2011). Sulfur-containing amino acids as markers of stress. Buletinul Academiei de Ştiinţe. Ştiinţele vieţii, 3(315), 50-62.

Gotovsky, D. G., Sobolev, D. T., \& Gisko, V. N. (2018). Indicators of protein metabolism of replacement chickens when they are grown in conditions with various microbial air pollution. Veterinary Journal of Belarus, 2(9), 6-8.

Havenstein, G. B., Ferket, P. R., \& Qureshi, M. A. (2003). Growth, livability, and feed conversion of 1957 versus 2001 broilers when fed representative 1957 and 2001 broiler diets. Poult. Sci, 82(10), 15001508. doi: $10.1093 / \mathrm{ps} / 82.10 .1500$.

Kaneko, J. J., Harvey, J. W., Bruss, M. L. et. al. (2008). Clinical biochemistry of domestic animals. Academic press, $6^{\text {th }}$ edition. doi: $10.1016 /$ B978-0-12-3704917.00006-4.

Khlybova, S. V., \& Cirkin, V. I. (2006). Free L-histidine as one of the regulators of physiological processes. Vyatka medical bulletin, 3-4:, 44-48. URL: http://elib.kirovgma.ru/sites/default/files/vmv/2006/v0 603-4.pdf.

Khuzhakhmetova, L. K., \& Teply, D. L. (2016). Pharmacological correction of lipid peroxidation and peroxide hemolysis of red blood cells in mature rats during immobilization stress. Physiology, Natural Sciences, 2(55), 66-71.

Komarova, N. V., \& Kamentsev, Ya. S. (2006). A practical guide to the use of capillary electrophoresis systems "Kapel". OOO "Veda", 212.

Kondrakhin, I. P., Arkhipov, A. V., \& Levchenko, V. I. (2004). Methods of veterinary clinical laboratory diagnostics. Reference, 171-172.

Kuznyak, G., \& Savchuk, L. (2017). Protein nutrition of poultry and its dependence on age. Agricultural science and education of Podillya, 1, 334-336.

Kyryliv, B. Ya., Ratych, I. B., Gunchak, A. V., \& Fedorovych, E. I. (2015). Biological and metabolic features of different species of poultry. Scientific Messenger of LNU of Veterinary Medicine and Biotechnologies. Series: Agricultural Sciences, 17(61), 71-80. URL: https://nvlvet.com.ua/index.php/agriculture/article/vie w/3552/3518.

Lushchak, V. I., Bagnyukova, T. V., \& Luzhna, L. I. (2006). Indices of oxidative stress. 2. Lipid peroxides. Ukr. biochemistry magazine, 78(5), 113-119. URL: https://pubmed.ncbi.nlm.nih.gov/17494327.

Machida, N., \& Aohagi, Y. (2001). Electrocardiography, heart rates, and heart weights of free living birds. J. Zoo Wild Med, 32(1), 47-54. doi: 10.1638/10427260(2001)032[0047:ehrahw]2.0.co;2.

Martínez, Y., Li, X., Liu, G. et al. (2017). The role of methionine on metabolism, oxidative stress, and diseases. Amino Acids, 49(12), 2091-2098. doi: 10.1007/s00726-017-2494-2.

Meerson, F. Z. (2001). Heart protection against ischemic lesions: the role of stress-limiting system sand stabilizing myocardial structure. Russian journal of cardiology, 5, 
49-59. URL: https://russjcardiol.elpub.ru/jour/article/ view/2058?locale $=$ en US.

Messina G., Vicidomini C., Viggiano A. et al. (2012). Enhanced parasympathetic activity of sportive women is paradoxically associated to enhanced resting energy expenditure. Auton. Neurosci. Basic Clin, 169(2), 102-106. doi: 10.1016/j.autneu.2012.05.003.

Navarro, X. (2002). Physiology of the autonomic nervous system. Rev. Neurol., 35(6), 553-562. doi: 10.33588/rn.3506.2002013.

Opalovskaya, G. M. (2001). Circadian rhythms of autonomic parameters during mental and physical activity. Bulletin of experimental biology and medicine, 132(5), 1029-1033. doi: 10.1023/a:1017943903292.

Polumbryk, M., Ivanov, S., \& Polumbryk, O. (2013). Antioxidants in food systems. Mechanism of action. Ukrainian journal of food science, 1, 15-40.

Püschel, G. P. (2004). Control of hepatocyte metabolism by sympathetic and parasympathetic hepatic nerves. The Anatomical Record Part A: Discoveries in Molecular, Cellular, and Evolutionary Biology, 280(1), 854-867. doi: 10.1002/ar.a.20091.

Reddy, B. S., Reddy, P. A., \& Venkatasivakumar, R. A. (2016). Study on electrocardiographic patterns in turkeys (Meleagris gallopavo). Inter J. Vet. Sci., 5(2), 79-82.

Stalnaya, I. D. (1977). Method for determination of diene conjugation unsaturated higher fatty acids. Modern methods in biochemistry, 63-64.
Studenok, A. A., Shnurenko, E. O., Trokoz, V. O., Karpovsky, V. I., Zhurenko, O. V., Krivoruchko, D. I. (2020). A method of assessing the tone of the autonomic nervous system in chickens. Ukraine Patent 142943. inventors; Nat. Univ. Life and Environm. Sci. Ukraine, assignee (2020, Jul 10).

Sturkie, P. D. (1986). Avian Physiology 4thed. Springer, 167-191.

Thrall, M. A., Weiser, G., Allison, R. W. et al. (2012). Veterinary hematology and clinical chemistry. John Wiley $\&$ Sons, $2^{\text {th }}$ edition.

Trenzado, C., Hidalgo, M. C., Garsia-Gallego, M. et al. (2005). Antioxidant enzymes and lipid peroxidation in sturgeon Acipenser naccarii and trout Oncorhynchus mykiss. A comparative study J. Aquaculture, 254(14), 758-767. doi: 10.1016/j.aquaculture.2005.11.020.

Tybinka, A. M. (2011). Features of variation-pulsometric indexes of chickens. Scientific Messenger of LNU of Veterinary Medicine and Biotechnologies, 13(4(50)), 446-449. URL: http://nbuv.gov.ua/UJRN/nvlnu_2011_ 13 4\%281\%29 84.

West, B. J. (2010). The wisdom of the body; a contemporary view. Front. Physiol., 1(1), 1-2, doi: 10.3389/fphys.2010.00001.

Zenkov, M. K., Lankin, V. Z., \& Menshikova, E. B. (2001) Oxidative stress. Biochemical and pathophysiological aspects, Moscov, MAIK "Nauka/Interperiodika URL: https://search.rsl.ru/ru/record/01000736030. 